Vol. 8, Issue 12, December 2021

DOI: $10.17148 /$ IARJSET.2021.81207

\title{
Women Entrepreneurship in beauty parlour services: A study in Dakshina Kannada District
}

\author{
Suchitra ${ }^{1}$, Ramesh Pai ${ }^{2}$ \\ ${ }^{1}$ Assistant Professor, St.Aloysius College (Autonomous), Mangalore \\ ${ }^{2}$ Research Professor, College of Management and Commerce, Srinivas University
}

\begin{abstract}
The contribution of women in the development of economies is incredible. In the past, her role was restricted within the four walls. At present can find her in the field of society, such as education, politics, administration, sports, and many other fields. She knows how to manage and bring co-operation within the group. Through the motivation and support of her surroundings took her to the next step of starting her own ventures.

The modern era has been a blessing to society because it has opened up several chances, yet there is still a preconception in society that women are mainly designated for domestic chores and are incapable of taking responsibility. Women have defied such stigma recently by bringing to light their hidden abilities, talents, and ideas by participating in challenges. However, there are several challenges in their path to successful entrepreneurs.

Although various forms of training and financial aid are regularly supplied through various government and self-help group initiatives. This study focuses on what are the motivations behind women entrepreneurs to start with a beauty parlour and what are the challenges they have faced and facing continuing the venture and give some suggestions based on the study. This study covers Women Entrepreneurs in connection with beauty parlour services in Dakshina Kannada District. Random sampling technique is employed for the study.
\end{abstract}

Keywords: Women entrepreneurs, beauty parlour, motivation, problems, prospects.

\section{INTRODUCTION:}

Women is the power. She plays very important role in the wellbeing of family as well as in the development of the economy. The contribution of the family and the state to the development of female entrepreneurs is very important. There are many programs launched by the government to promote female entrepreneurship. However, the awareness of these systems is very low. An effort is required from all the levels of the society to reach the needy then only we can say it's effective. There are around 58.5 million entrepreneurs all over India out of this only $14 \%$ are women. 13.45 million People are employed by Indian-women owned businesses [1]. Beauty sector doing very well in the market. It has become the backbone of most of the family. Starting from parlour it reached to place website based portal for the trading of beauty products. The founder of NYKAA Falguni Nayar recorded a history in converting her e-commerce business on beauty products into a joint stock company by going through the IPO's. NYKAA shares are listed on the stock exchange with a premium of $80 \%$.This reveals the strength of her ideas and innovations in the field of business [2]. She became second wealthiest promoter in India [3].

\section{LITERATURE REVIEW:}

[4]Study is mainly focused on how group entrepreneurship will help the members in upgrading their status of living, creativity, co-ordination and motivation in the group. The role of SKDRP in the development of group entrepreneurship is taken as the base for the study. [5] Updating in the field of technology is the need of the hour. Otherwise business will be outdated. Without new ideas, economic and technological innovations survival in the market is big challenge.

[6] Group entrepreneurship not only helps the member to get financial benefit as well as it brings co-ordination among the group members as well they are motivated by the well trained professionals in engaging the business very efficiently. Individualised treatment and follow-up services boosted the growth of the business. [7] Success of women entrepreneurship mainly depends upon business characteristics. [8] Empowerment of women mainly ruled by family members. Support from the family, government is necessary for the establishment and successful continuation of business. [9] Women entrepreneur's facing problems regarding availability of finance and method of availing the facility. [10]Compare to male, female are very less access equity capital even if they lead in the market.

[11] Women always share the information and wants to work in group. This brings success and opportunities to grow further in their business.[12]Support from the family always helps women to start their own business. [13]Women entrepreneurs from informal sector are running business successfully but they don't have support from the government 


\title{
International Advanced Research Journal in Science, Engineering and Technology
}

\author{
Vol. 8, Issue 12, December 2021
}

DOI: $10.17148 /$ IARJSET.2021.81207

and family. If they are trained will emerge as a story of success. [14]Major challenges the women entrepreneurs face are poor financial background, low ability of risk bearing, lack of skilled education etc. [15]The performance expectancy, effort expectancy are major factors influencing women entrepreneurs with regards to e-commerce. [16]From the cases of Malavika it is observed that she knows her contribution to the economy is commendable but bothered about future challenges.

[17]Even after facing many Challenges Indian women is now trying to become economically independent. Government has come forward with many concessions, facilities and incentives for women entrepreneur. [18]50\% of the population of the Karnataka state is Women. Women's empowerment and labour force participation are taking place in Karnataka.

\section{OBJECTIVE:}

1. To study the motivation factor behind the establishment of beauty parlour.

2. To Study the problems and challenges faced by beauty parlour entrepreneurs in the Dakshina Kannada District. 3. To recommend suggestions based on the study

\section{RESEARCH METHODOLOGY:}

This study focuses primarily on the motivations for starting a cosmetology shop and an analysis of the questions and challenges faced by female entrepreneurs in the Dakshina Kannada district in relation to the cosmetology sector. Both primary and secondary data are used. Primary data is collected through a structured survey using random sampling. 62 respondents were selected for this survey. This survey covers the Dakshina-Kannada area.

\section{DATA ANALYSIS AND INTERPRETATION:}

The collected data was summarized in a table and the analysis was performed using a simple percentage analysis technique.

Demographic profile:

Demographic details were collected to know the background of the entrepreneurs such as age, marital status, and educational qualification to study the diversity of respondents in the research area. The details are given below

Table 1: Demographic Variables

\begin{tabular}{|l|l|l|l|}
\hline Variables & Category & Frequency & Percentage (\%) \\
\hline Age & Less than 30 & 15 & 24 \\
\hline & $30-40$ & 39 & 63 \\
\hline & Above 40 & 8 & 13 \\
\hline Marital status & Married & 47 & 75.8 \\
\hline & Unmarried & 15 & 24.2 \\
\hline $\begin{array}{l}\text { Educational } \\
\text { Qualification }\end{array}$ & SSLC & 23 & 37 \\
\hline & & & \\
\hline & PUC & 31 & 50 \\
\hline & Degree & 8 & 13 \\
\hline Nature of the family & Post Graduate & nil & nil \\
\hline & Joint & 15 & 24 \\
\hline Family size & Nuclear & 47 & 76 \\
\hline & Less than 4 & 39 & 63 \\
\hline & $4-6$ & 23 & 37 \\
\hline Family monthly Income & Less than ₹.25000 & 39 & nil \\
\hline & ₹25000-₹30000 & 23 & 37 \\
\hline & More than ₹30000 & nil & nil \\
\hline
\end{tabular}

(Source: Primary data)

Age: It was found that $63 \%$ of the respondents were between the age group of $30-40$ and $24 \%$ from the age group of lea than 30 .

Marital Status: Majority of the respondents (75\%) are married. 


\title{
International Advanced Research Journal in Science, Engineering and Technology
}

\author{
Vol. 8, Issue 12, December 2021
}

DOI: $10.17148 /$ IARJSET.2021.81207

Education qualification: around $50 \%$ of the respondents are attained pre university education, $37 \%$ of them are done with secondary education remaining are graduated.

Family size: $63 \%$ of the respondents family with of less than four members and remaining fall between 4-6 categories. Nature of the family: $76 \%$ of the respondents from the nuclear family. Family monthly Income: Family income of $63 \%$ respondents fall in the less than ₹25000 monthly income category remaining 37\% between ₹25000-₹30000 categories. Business Profile: Business details are collected to evaluate the size of the business, area, nature, and training.

Table2: Features of the business

\begin{tabular}{|l|l|l|l|}
\hline Variables & Category & Frequency & Percentage (\%) \\
\hline Nature of the beauty parlour & Rental Building & 39 & 63 \\
\hline & Part of the house & 8 & 13 \\
\hline Location of the beauty parlour & Own shop & 15 & 24 \\
\hline & Urban area & 23 & 37 \\
\hline & Semi-urban area & 23 & 37 \\
\hline Registration of beauty parlour & Rural area & 16 & 26 \\
\hline & Registered & 54 & 87 \\
\hline Attended beautician training programme & Not-registered & 8 & 13 \\
\hline & Yes & 16 & 26 \\
\hline Done with beautician programme & No & 46 & 74 \\
\hline & Yes & 54 & 87 \\
\hline
\end{tabular}

(Source: Primary data)

From the above table it is clear that $63 \%$ of the respondents run their business rental building. $24 \%$ of them are having own shop and others run their business as extension of their house. Majority of them are having their parlour in (37\%) in urban and semi-urban areas. Only $83 \%$ of them are registered their business. $74 \%$ of the respondents are not interested in attending beauty training programmes but $87 \%$ of the respondents completed their beautician courses.

Table 3: Table showing Factor motivating Women entrepreneurship:

\begin{tabular}{|l|l|l|}
\hline Variables & Frequency & $\begin{array}{l}\text { Percentage } \\
(\boldsymbol{\%})\end{array}$ \\
\hline Family income supplementation & 14 & 23 \\
\hline To utilize the skills & 14 & 23 \\
\hline To have better status in the society & 9 & 15 \\
\hline Easy to set up at home & 7 & 11 \\
\hline Utilization of time & 8 & 13 \\
\hline Family inspiration and background & 10 & 15 \\
\hline
\end{tabular}

(Source: Primary data)

From the above table it's clear that $23 \%$ of the respondents opine that they are supported by family income and their skills to start their own beauty parlour. Around $15 \%$ feels that having own business brings better status in the society and family inspiration motivated them to start their career. Others find that it is easy to setup and can spend time fruitfully.

Table 4: Table showing factors affecting women entrepreneurs:

\begin{tabular}{|l|l|l|}
\hline Variables & Frequency & $\begin{array}{l}\text { Percentage } \\
(\%)\end{array}$ \\
\hline Family obligations & 19 & 30 \\
\hline Male domination & 0 & 0 \\
\hline Lack of proper training & 14 & 23 \\
\hline Poor credit facilities & 0 & 0 \\
\hline Lack of finances & 19 & 31 \\
\hline Lack of self confidence & 10 & 16 \\
\hline
\end{tabular}


Vol. 8, Issue 12, December 2021

DOI: $10.17148 /$ IARJSET.2021.81207

(Source: Primary data)

\begin{tabular}{|l|l|l|}
\hline No-risk bearing capacity & 0 & 0 \\
\hline Dual role of women & 0 & 0 \\
\hline
\end{tabular}

The above table depicts that $31 \%$ of the respondents feels that the major issue in set up of business is finance, $30 \%$ says are having issue on family obligations and $23 \%$ respondents feels that they don't have adequate training programmes to enhance their skills.

Table 5: Table showing problems faced by women entrepreneur:

\begin{tabular}{|l|l|l|}
\hline Variables & Frequency & $\begin{array}{l}\text { Percentage } \\
(\%)\end{array}$ \\
\hline Work life balance & 14 & 23 \\
\hline Poor credit facilities & 8 & 13 \\
\hline $\begin{array}{l}\text { Lack of sufficient raw materials, technology and } \\
\text { suppliers }\end{array}$ & 4 & 7 \\
\hline Lack of proper training & 7 & 11 \\
\hline Lack of government support and subsidies & 15 & 24 \\
\hline Increase in the rent & 7 & 11 \\
\hline Lack of advertisement & 7 & 11 \\
\hline $\begin{array}{l}\text { Tough competition from longer and established } \\
\text { units }\end{array}$ & 0 & 0 \\
\hline
\end{tabular}

(Source: Primary data)

It's clear from the above table that around $24 \%$ respondents feels that they are not getting support and subsidies from the government and finding (23\%) difficult with balancing their work with the life. Increased rent, lack of advertisement and lack of proper training are the other issues they are facing with their business.

\section{FINDINGS:}

- Majority of the respondent's (63\%) were between the age group of 30-40. 75\% of them married and 76\% of them come from Nuclear family.

- $\quad 87 \%$ of the respondents have completed their secondary education (SSLC or PUC).

- $\quad$ Most of them had a monthly income of less than 25,000.

- The majority of the people surveyed operate in rental buildings..

- Majority of them are having their parlour in (72\%) in urban and semi-urban areas.

- $\quad$ Family income and skills are the main driving factor in the establishment of beauty parlour.

- Majority of the respondents feels that the major issue in set up of business is finance and family obligations.

- The main issues in running business are lack of support from the government and challenges in work life balancing.

\section{SUGGESTIONS:}

- There are various programmes offered by the government for the women empowerment but awareness towards this is lacking. So government must come up with the programme to reach the women effectively.

- It's observed that most of the married women are in this sector. To bring even unmarried women the adequate training programme can be initiated in the college levels.

- Government can take the help of the District industrial centre, self-help groups to reach the women entrepreneurs.

\section{CONCLUSION:}

Women are contributing in all the fields. The up gradation in the technology boosting the women to start their own business by shifting their role from job seekers into job givers. For women to succeed in business, they need continuous support from their families and government. No more gender inequalities when it comes to the economic growth both are equal contributors but risk bearing capacity of the women must be developed. 


\title{
International Advanced Research Journal in Science, Engineering and Technology
}

\author{
Vol. 8, Issue 12, December 2021
}

DOI: $10.17148 /$ IARJSET.2021.81207

\section{REFERENCES:}

[1]. https://app.helloalice.com/resources/content/3819

[2]. https://economictimes.indiatimes.com/markets/ipos/fpos/nykaa-makes-stellar-debut-on-stock-exchanges-shares-list-at-a-premium-ofal(Kamberidou, 2013)most-80/articleshow/87618896.cms

[3]. https://www.business-standard.com/article/companies/nykaa-ceo-falguni-nayar-is-india-s-richest-self-made-woman-promoter121111100027_1.html

[4]. 1564650, V. J.-A. at S., \& 2010, undefined. (n.d.). Group Entrepreneurship in Dakshina Kannada District of Karnataka: A Field Based Study article on WE. Papers.Ssrn.Com. Retrieved October 29, 2021, from https://papers.ssrn.com/sol3/papers.cfm?abstract_id=1564650

[5]. Chowdhury, T. Y., Yeasmin, A., \& Ahmed, Z. (2018). Perception of women entrepreneurs to accessing bank credit. Journal of Global Entrepreneurship Research, 8(1). https://doi.org/10.1186/S40497-018-0119-1

[6]. Goswami, A., Research, S. D.-B. and E., \& 2016, undefined. (n.d.). E-commerce adoption by women entrepreneurs in India: an application of the UTAUT model article on WE. Ideas.Repec.Org. Retrieved November 12, 2021, from https://ideas.repec.org/a/mth/ber888/v6y2016i2p440454.html

[7]. K, K. D., of, K. V. K.-I. J., \& 2010, undefined. (n.d.). SKDRDP's Successful Experiment with Group Entrepreneurship. article on WE. Search.Ebscohost.Com. Retrieved October 29, 2021, from http://search.ebscohost.com/login.aspx?

[8]. Kamberidou, I. (2013). Women entrepreneurs: 'we cannot have change unless we have men in the room.' Journal of Innovation and Entrepreneurship, 2(1), 6. https://doi.org/10.1186/2192-5372-2-6

[9]. Knowledge, N. S.-A. search for, \& 2017, undefined. (n.d.). Women Entrepreneurship-Innovation and Management with Reference to Kerala and Karnataka article on WE. Ischolar.Info. Retrieved October 29, 2021, from http://ischolar.info/index.php/Anveshana/article/view/168836

[10]. Mishra, G., Research, U. K.-I. J. of S. and, \& 2014, undefined. (n.d.). Rural women entrepreneurs: Concerns \& importance article on WE. Citeseer. Retrieved October 29, 2021, from https://citeseerx.ist.psu.edu/viewdoc/download?doi=10.1.1.657.9184\&rep=rep1\&type=pdf

[11]. Orser, B. J., Riding, A. L., \& Manley, K. (2006). Women entrepreneurs and financial capital. Entrepreneurship: Theory and Practice, 30(5), 643-665. https://doi.org/10.1111/J.1540-6520.2006.00140.X

[12]. Patgaonkar, M., Entrepreneurship, G. B.-T. I. J. of, \& 2012, undefined. (n.d.). Rural Women Entrepreneurs in the Informal Sector of India article on WE. Papers.Ssrn.Com. Retrieved November 12, 2021, from https://papers.ssrn.com/sol3/papers.cfm?abstract_id=2154759

Pathak, A. A., \& Varshney, S. (2017). Challenges faced by women entrepreneurs in rural India: The case of Avika. International Journal of Entrepreneurship and Innovation, 18(1), 65-72. https://doi.org/10.1177/1465750316686245

[13]. Rao, P., Applied, M. S.-I. J. of, \& 2018, undefined. (2018). Women Empowerment to Women Entrepreneurship-A Success Story of Karnataka article on WE. Ripublication.Com, 13(23), 16683-16687. https://www.ripublication.com/ijaer18/ijaerv13n23_69.pdf

[14]. Rao, V., Venkatachalm, A., \& Joshi, H. (2012). Challenges faced by women entrepreneurs running micro, small and medium scale fashion and apparel business: a study on fashion and apparel enterprises in article on WE. https://eprints.manipal.edu/139817/

[15]. Sangolagi, K., Advancement, M. A.-I. J. of, \& 2016, undefined. (2018). Women entrepreneurs article on WE. Researchgate.Net, 13(23), $16683-16687$. Sangolagi/publication/316430274_Women_Entrepreneurs/links/58fd9b654585152eded4bd42/Women-Entrepreneurs.pdf

[16]. Technology, P. K.-I. J. of A. S. \&, \& 2015, undefined. (n.d.). A study on women entrepreneurs in India article on WE. Academia.Edu. Retrieved November 12, 2021, from https://www.academia.edu/download/55801993/IJASTRE_552015.pdf

[17]. Welsh, D., Memili, E., Knowledge, E. K.-J. of I. \&, \& 2016, undefined. (n.d.). An empirical analysis of the impact of family moral support on Turkish women entrepreneurs article on WE. Elsevier. Retrieved November 12, 2021, from https://www.sciencedirect.com/science/article/pii/S2444569X16000147 